\title{
Analysis of anatomy and configuration of the canal system of the maxillary second premolar in the population of Bosnia and Herzegovina
}

\section{Brankica Davidović, Ljiljana Bjelović, Igor Radović, Bojana Davidović, Svjetlana Janković, Smiljka Cicmil}

University of East Sarajevo, Faculty of Medicine Foca, The Republic of Srpska, Bosnia and Herzegovina

Primljen - Received: 09/11/2020

Prihvaćen - Accepted: 01/04/2021

\section{Corresponding author:}

Brankica Davidović, PhD, DDS, MSC

Studentska 5, 73300 Foca

davidovicbrankica@yahoo.com

Copyright: @2021 Brankica Davidović et all. This is an Open Access article distributed under the terms of the Creative Commons Attribution 4.0 International (CC BY 4.0) license.

\begin{abstract}
Summary
Introduction. Successful endodontic treatment depends upon the clinician's knowledge and ability to recognize and diagnose the presence of anatomical and morphological variations of the root and canal system. The aim of this study was to establish the number of roots and root canal configurations of the maxillary second premolar in the population of Bosnia and Herzegovina.
\end{abstract}

Methods. The study sample was comprised of 150 maxillary second premolar teeth extracted for orthodontic or prosthetic reasons. Endodontic drills were used for trepanation of cavum dentis, and the number and patency of each root canal were determined by K- expander \# 15. Then, the samples were decalcified, made transparent and colored, to enable 3D viewing of the canal system. Decalcified teeth were observed from two projections (clinical and approximal) and analyzed in detail with a magnifying glass under $3 \times$ and $5 \times$ magnification in order to determine the number of roots, number of canals, root canal configuration using Vertucci's classification and number of anastomoses between canals. Statistical significance was obtained using Chi-square test.

Results. The results obtained by decalcification of the teeth showed that, by radiographic analysis from the clinical projection, all the teeth had a single root. While, by the analysis from the approximal projection, $94.0 \%$ had one, $6.0 \%$ two roots. From the approximal projection, $70.7 \%$ with a single root canal and $29.3 \%$ with two root canals are visualized. The most common type of root canal configuration in the maxillary second premolars was Type I in both clinical (87.9\%) and approximal projection (40.7\%).

Conclusion. These results emphasize the importance of knowing the variations in root canal morphology, because excluding the possibility of morphological variations can lead to failure of endodontic therapy.

Key words: maxillary second premolar, root canal, decalcification

\section{Introduction}

The knowledge of the root canal morphology as well as of possible anatomical and morphological variations in the number of roots and the configuration of canal system, are the basic prerequisites for the success of an endodontic treatment [1-3]. 
Untreated root canals in irreversible pulp damage lead to persistence of microorganisms and necrotic tissue within the canal itself, which can cause the consequent development of a pathological process in periodontal tissue. Anatomic variations of the root canal system are the most frequent causes of the therapy negligence [2]. Previous studies have shown that premolars can differ significantly in the number of roots and root canals, as well as that maxillary premolars have very variable configuration of the internal canals, which can vary depending on the race and geographic origin. The maxillary second premolar is a tooth of complex morphological structure with frequent variations in the canal system and presents a challenge for all clinicians during endodontic treatment $[2,4-10]$. By the data available, the frequency of one-root maxillary second premolar varies from $69.6 \%$ to $90.3 \%$, the frequency of two-root maxillary second premolar varies from $9.7 \%$ to $29.7 \%$, while the frequency of three-root maxillary second premolar varies from 0 to $1.6 \%$ [7-10].

From the coronary part to the apex of the root, different variations of the canal can be observed, i.e. the canal may bifurcate, divide and/or merge at different levels of the root. In the maxilla, premolars show the greatest number of canal variations, especially the second premolar [4,7]. Studies describe different classifications of the root canals of permanent teeth, including the classification by Weine [11], Vertucci [1] and Gulabivala [12]. The Vertucci's classification is considered as the most frequently used, encompassing pulp space which can have eight different configurations: Type I (1), Type II (2-1), Type III (1-2$1)$, Type IV (2), Type V (1-2), Type VI (2-1-2), Type VII (1-2-1-2) and Type VIII (3). Maxillary second premolars are considered to be the most demanding teeth for endodontic treatment, due to the number of roots and canals, the course and longitudinal concavity of the root, different configuration of the pulp cavity and difficulties in visualizing of the apical foramen by radiographs $[1,13,14]$. Various in vivo and in vitro methods were used to examine the anatomy of the root canal. In vivo techniques include clinical assessment during treatment, retrospective analysis of a patient's dental history, conventional radiographic examinations as well as advanced radiographic techniques such as cone-beam computed tomography using a cone-shaped X-ray beam (CBCT) [15-17]. On the other hand, in vitro methods include cleaning and staining of tooth root canals $[1,18]$, microscopic analysis of the root cross-section [11], methods based on filling and decalcification of canals, the analysis of conventional radiographic images and the use of three-dimensional modalities such as micro-computed tomography ( $\mu-\mathrm{CT}$ ) $[19,20]$. Although different studies utilized various techniques for the root morphology assessment, it is registered that the most precise information can be gathered ex vivo, by demineralization and staining [1]. This technique makes the radiography with a canal instrument unnecessary, retaining the original shape and relationship of the canals and providing a three-dimensional view of the root canals $[1,5,8]$. The insertion of contrast dye into the canal system, followed by demineralization and the process of making the teeth transparent by immersing them into methyl salicylate, xylene or styrene, remains one of the most frequently used methods of testing the configuration of the canal system $[1,8]$.

The aim of this study was to establish the number of roots and root canal configurations of the maxillary second premolar in the population of Bosnia and Herzegovina.

\section{Methods}

One hundred and fifty human maxillary second premolar teeth, extracted for orthodontic or prosthetic reasons, were collected as a sample for this study. Teeth were collected from patients aged from 20 to 40 who came to the Specialist Dentistry Center of the Faculty 
of Medicine Foca, University of East Sarajevo, Bosnia and Herzegovina. The criteria for the teeth inclusion into research were: intact teeth, partially preserved dental crowns, teeth with fillings, teeth that have not been previously endodontically treated, teeth with no signs of pathological resorption and physical damage of the root, teeth with fully formed and developed roots.

After extraction, the teeth were rinsed under running water and mechanically cleaned of soft tissue residues and concretions (Figure $1 \mathrm{a}, 1 \mathrm{~b})$. All samples were stored in plastic containers with physiological saline in the freeze

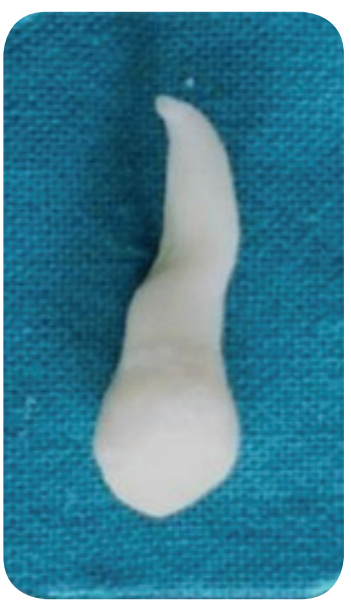

(a)

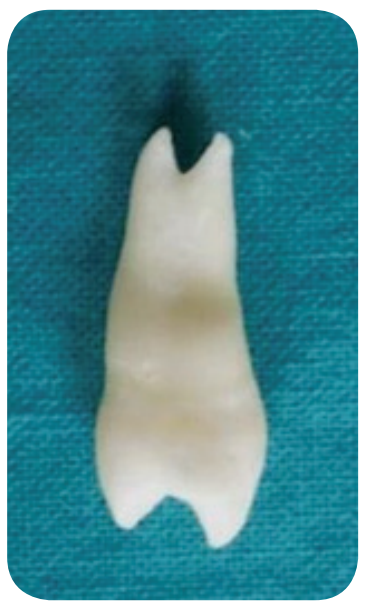

(b)

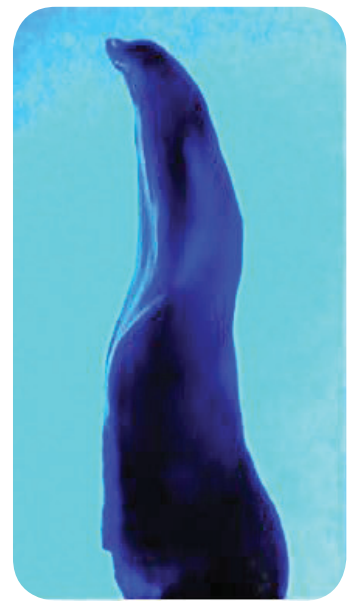

(c)

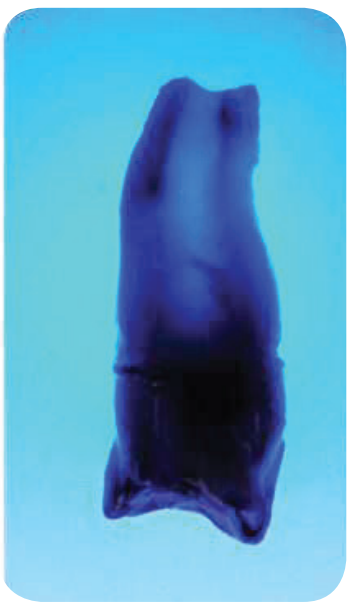

(d)

Figure 1. Extracted maxillary second premolar $(a, b)$, decalcified tooth from the clinical projection (c), decalcified tooth from the approximal projection (d)

until the beginning of laboratory research, at a temperature below $-7^{\circ} \mathrm{C}$. Diamond and tungsten carbide round drills of a high-circulation water-cooled machine were used to remove caries and existing fillings (Meisinger, Germany).

The remnants of the coronal pulp were removed with an excavator and an ultrasound machine. Every specimen was immersed in a solution of $5.25 \%$ sodium hypochlorite for 48 hours, in order to decompose and easily remove organic detritus from root canals. of decalcification in order to define anatomical features of the canal system. The samples were decalcified, made transparent and colored, to enable $3 \mathrm{D}$ viewing of the canal system (Figure 1c, 1d). The teeth were decalcified in $5 \%$ nitric acid for 72 hours. The acid solution was changed daily, and the end point of decalcification was determined by periodic radiographs. Thereafter, the teeth were washed under running water in order to remove the traces of nitric acid, dried and dehydrated using increasing concentrations of ethanol (70\% 


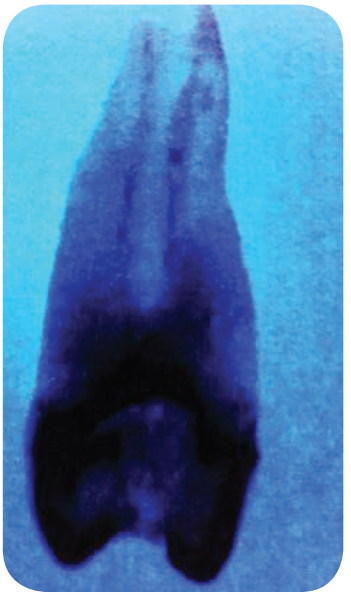

(a)

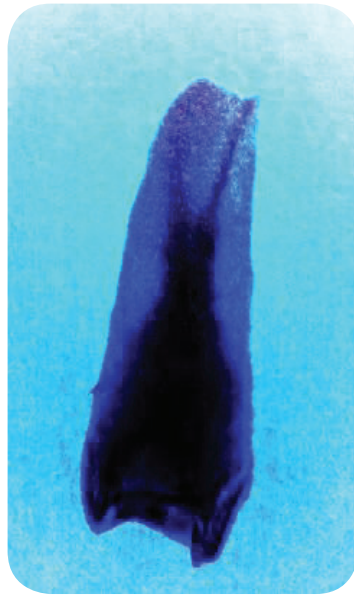

(b)

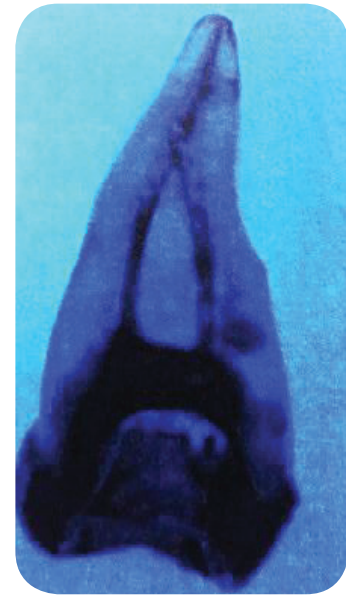

(c)

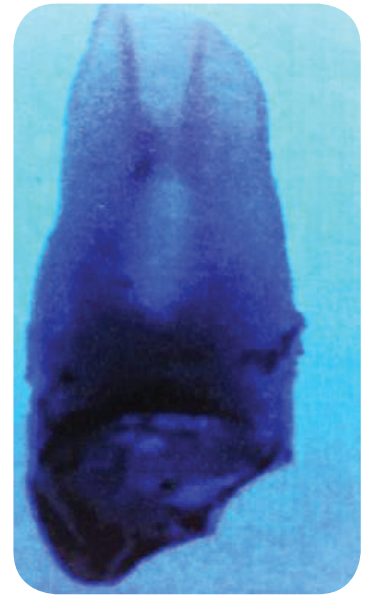

(d)

Figure 2. Different patterns of root canal systems by Vertucci classification $(a, b, c)$, localization of anastomosis between canals in the medial third (d)

for 12 hours, then $90 \%$ for 8 hours and $100 \%$ for 1 hour). Decalcified teeth were placed into glass containers filled with methyl salicylate for 6 hours in order to reach transparency, while hematoxylin-eosin stain was injected into the access cavity.

Decalcified teeth were observed from two projections (clinical and approximal) and analyzed in detail with a magnifying glass under $3 \times$ and $5 \times$ magnification in order to determine the number of roots, canals, number of apical foramina and the location of anastomoses between canals (Figure 2a, 2b, 2c). The root configurations were categorized based on Vertucci's classification from 1984, as follows:

Type 1: a single canal is present from the pulp chamber to the root apex.

Type 2: two separate canals leave the pulp chamber and join at certain level of the apex to form one canal, which ends in one foramen.

Type 3: one canal leaves the pulp chamber, divides into two within the root, and then merges to exit through one canal.

Type 4: two separate and distinct canals are present from the pulp chamber to the apex.

Type 5: single canal leaves the pulp chamber but divides into two separate canals with two separate apical foramina.
Type 6: two separate canals leave the pulp chamber but join at the midpoint and divide again into two separate canals with two separate apical foramina before exiting from apex.

Type 7: one canal leaves the pulp chamber, divides and rejoins within the canal, and at the apex third finally divides again into two distinct canals with two separate apical foramina.

Type 8: three canals leave the pulp chamber and run independently towards the apex as three divides apex foramina.

In order to determine the location of anastomoses, decalcified teeth were observed from two projections (clinical and approximal) and analyzed in detail with a magnifying glass under $3 \times$ and $5 \times$ magnification in the cervical, middle, and apical thirds of the root canal (Figure 2d).

When statistical analysis of data is concerned, a statistical software program SPSS 15,0 was used (IBM Corp., Armonk, NY, USA). The relationship among the number of roots and canals and the Vertucci's classification was obtained using Chi-square test.

The significance level was defined as $5 \%$ (typically $\mathrm{p}<0.05$ ). 


\section{Results}

Within decalcified teeth, the analysis of the results obtained from the clinical projection of 150 extracted second maxillary premolars revealed that $100 \%$ of teeth possess a single root. However, observing from approximal projection $94 \%$ of teeth had a single root, and $6 \%$ had two roots. Statistical analysis showed a significant difference between the values obtained in the clinical and approximal projection $(\mathrm{p}<0.05)($ Table 1$)$. Also, Table 1 showed
$(87.9 \%)$, and approximal projection $(40.7 \%)$. The canal configuration Type II was detected in $8 \%$ of roots observed from clinical, or $30 \%$ observed from approximal projection. Type VI, VII and VIII by Vertucci were not detected.

The analysis of the present anastomoses in decalcified teeth between root canals in clinical projection revealed that 110 teeth did not possess anastomoses, while $24(16.0 \%)$ teeth had anastomoses in the cervical third of the root. Anastomoses were detected in a certain number in the middle (8.7\%) and apical third

Table 1. Distribution of morphologic configurations in the root canal system of maxillary second premolars

\begin{tabular}{|c|c|c|c|}
\hline & & $\begin{array}{c}\text { Clinical projection } \\
\text { N (\%) }\end{array}$ & $\begin{array}{c}\text { Approximal projection } \\
\text { N (\%) }\end{array}$ \\
\hline \multirow{4}{*}{ Frequency of roots } & one & $150(100)$ & $141(94.0)$ \\
\hline & two & $0(0.0)$ & $9(6.0)$ \\
\hline & total & 150 & \\
\hline & $\mathrm{p}$ & \multicolumn{2}{|c|}{ p0.001 } \\
\hline \multirow{4}{*}{ Frequency of root canals } & one & $142(94.7)$ & $106(70.7)$ \\
\hline & two & $8(5.3)$ & $44(29.3)$ \\
\hline & total & 150 & 150 \\
\hline & $\mathrm{p}$ & \multicolumn{2}{|c|}{$\mathrm{p}<0.001$} \\
\hline
\end{tabular}

$\mathrm{N}$ - sample size

the distribution of the number of root canals of the second maxillary premolars. The radiograph analysis of decalcified teeth observed from clinical projection revealed that $94.7 \%$ had a single root canal, while $5.3 \%$ of teeth had two canals. On the other hand, the observation from the approximal projection showed that $70.7 \%$ of teeth had a single canal, while $29.3 \%$ had two canals. A highly statistically significant difference was observed in the number of root canals between clinical and approximal projection $(\mathrm{p}<0.001)$.

Table 2 presents the distribution of configuration types of root canals according to Vertucci's classification of the maxillary second premolars. While analyzing decalcified teeth, Type I was the most prevalent in both clinical
Table 2. Configuration of canal systems of the second maxillary premolars by Vertucci's classification

\begin{tabular}{ccc}
\hline & $\begin{array}{c}\text { Clinical } \\
\text { projection } \\
\mathrm{N}(\%)\end{array}$ & $\begin{array}{c}\text { Approximal pro- } \\
\text { jection } \\
\mathrm{N}(\%)\end{array}$ \\
\hline Type I & $132(87.9)$ & $61(40.7)$ \\
Type II & $12(8.0)$ & $45(30.0)$ \\
Type III & 0 & $4(2.7)$ \\
Type IV & $3(2.0)$ & $24(16.0)$ \\
Type V & $3(2.0)$ & $16(10.7)$ \\
Type VI & 0 & 0 \\
Type VII & 0 & 0 \\
Type VIII & 0 & 0 \\
Total & 150 & 150 \\
$\mathrm{p}$ & & $\mathrm{p}<0.001$ \\
\hline
\end{tabular}

$\mathrm{N}$ - sample size 
(2.0\%). Observed from approximal projection, the greatest number of detected anastomoses was located in the middle third of the tooth $(42.0 \%)$, while smaller percentage of these was detected in cervical $(8.0 \%)$ and apical part of the tooth $(5.3 \%)$ (Table 3$)$.

Table 3. Localization of anostomoses among the root canals of the maxillary second premolars

\begin{tabular}{lcc}
\hline & $\begin{array}{c}\text { Clinical } \\
\text { projection } \\
\mathbf{N}(\%)\end{array}$ & $\begin{array}{c}\text { Approximal } \\
\text { projection } \\
\mathbf{N}(\%)\end{array}$ \\
\hline None & $110(73.3)$ & $67(44.7)$ \\
Cervical third & $24(16.0)$ & $12(8.0)$ \\
Middle third & $13(8.7)$ & $63(42.0)$ \\
Apical third & $3(2.0)$ & $8(5.3)$ \\
$\begin{array}{l}\text { Total } \\
\text { p }\end{array}$ & 150 & 150 \\
\hline
\end{tabular}

$\mathrm{N}$ - sample size

\section{Discussion}

The knowledge of the anatomy of the pulp chamber is of a crucial importance and leads to the very success of any endodontic treatment. The therapy of the root canals of the teeth possessing two or three roots is less successful comparing to one-root teeth [1]. Studies on the morphology of roots in different populations elicit the information related to the most frequent configurations as well as the possible variations in root canals [2-4]. Previous studies used different methods in order to estimate the internal morphology of teeth under laboratory and clinical conditions $[4,9,11,13,15,18-24]$. Laboratory methods are extremely precise, while the technique of decalcification and staining is considered as the gold standard when estimating the morphology of the root canal $[1,5,8]$. This technique enables three-dimensional analysis of root canals, maintaining the original shape of a canal. It consists of nitric acid decalcification, alcohol dehydration and methyl salicylate cleaning, which makes teeth transparent [8]. This in vitro study used double projected decalcification and staining in order to acquire data related to the number of roots and the configuration of canal system of the maxillary second premolars in the population of Bosnia and Herzegovina. Upon the radiograph analysis from clinical projection of the extracted human maxillary second premolars, the obtained results showed that all the teeth in this study had 1 root. On the other hand, approximal projection revealed $94 \%$ of teeth with a single root, and $6 \%$ teeth possessing two roots. Previous studies in different populations reported similar results and the incidence of a single root teeth varied from $69.6 \%$ to $90.3 \%[1,5,10,14,16]$. The findings of Pecora et al. [24] acquired from approximal projection and at a larger sample, which found the presence of a single root in $90 \%$ of the maxillary second premolars, also support this study. Moreover, while using approximal projection, this study revealed that $6 \%$ of the maxillary second premolars possess two roots, which is lot less comparing to several previous studies $[7,10]$, and, in accordance with the results of the following studies: Vertucci [13], Pecora et al. [24], Singla MG and Pada BK [30]. The frequence of three-root canals was extremely low in previous studies $(0.6 \%-1.6 \%)$. However, this study, using both projections, has not detected the presence of three roots in the maxillary second premolars $[7,10,27]$. The maxillary second premolars also display numerous variations in the number of roots in different geographical regions $[10,13]$. This study used the radiographic analysis from the clinical projection in order to prove that the upper maxillary premolars in $94.7 \%$ of cases possess a single root, in 5.3\% two roots, while three-root canals were not detected. The approximal projection analysis interestingly revealed that the frequency of a single root canal was $70.7 \%$, which shows higher percentage than previous studies [28,29], but lower than studies by Vertucci [13], Pecora et al [24] and 
Caliskan et al. [30]. Nevertheless, comparing the prevalence displayed in this study $(23.9 \%)$ to the results of the study by Yang et al [31], the presence of teeth with two canals was considerably higher $(54.3 \%)$ While the frequency of the maxillary second premolars possessing three roots in previous studies was $0.2 \%$ to $3 \%$ $[10,12,21,22,24,26]$, the presence of three canals was not detected in this study. These discrepancies may be explained by the usage of different research methodologies which reveal different results depicting wide variations in numbers of roots and root canals of the second maxillary premolars. In addition, there are differences in morphology of teeth among patients from different geographic and ethnic groups (different continents) and researchers need to be cautious when relying on the results acquired in researches conducted in different populations. The statistically significant difference in the number of roots and root canals from clinical and approximal projection can be explained by the fact that the superposition of roots or canals happened at clinical projection.

The most common configuration of root canals in the maxillary second premolars observed in this study was Type I in clinical $(87.9 \%)$, as well as in approximal projection $(40.7 \%)$. The greatest frequency of the canal configuration Type I was observed in Turkish population [5], as well as in Spanish [10], but Asian population showed difference [8], which complies with the results revealed by this study. The next most common type of canal system configuration in this study was Type II shown from approximal projection $(30 \%)$. An interesting observation is that this percentage of Type II from approximal projection is similar to the findings of Udayakumar and Mylswamy who found Type II configuration of root canal system in the Indian population in $33.6 \%$ of cases [32]. The frequency of Type IV of root canal system configuration in this study was low from both clinical projection $(2 \%)$, as well as from the approximal one (16\%). Using CBCT analysis, the study by Abella et al. [10] also observed a higher percentage of Type IV Vertucci's configuration (19.8\%), while Vertucci et al. [13] have reported the highest incidence of the Type IV (37.5\%). Differences in results between mentioned studies and this study may be due to different methods used for root canal visualization, racial and geographic factors, as well as the characteristics of the samples. Namely, in this study, Type III configuration of the canal system was the least frequent, while Vertucci types VI, VII and VIII were not detected in any sample. These findings differ from the results obtained in previous studies $[9,10,13]$.

Variations in the anatomy of root canals, i.e. the presence of anastomosis, significantly influence the outcome of the endodontic treatment. This study, using clinical projection, revealed the highest incidence of anastomoses in the cervical third of the root $(16 \%)$, which is less than in previous studies $[7,13,28]$, and in compliance with the findings of Sert and Bayirili [33]. The smallest number of anastomoses was detected in the apical third (2.0\%). By the analysis of radiograph from the approximal projection the following was reported, smaller number of anastomoses in the cervical third (8.7\%), while the apical third had $6.7 \%$. The most frequent anastomoses were detected in the middle third $(42.7 \%)$. Anastomoses have not been detected in $42 \%$ of cases. Comparing to our results, Singla and Pada [34] revealed that the most frequent anastomoses were detected in the cervical third $(60 \%)$, then in the middle third $(33.3 \%)$, and the least frequent anastomoses were detected in the apical third (6.7\%). Differences in findings may be due to individual variations in the way of interpreting of the localization of anastomoses. The knowledge of the localization of anastomoses is of the highest importance and represents the great challenge during the endodontic treatment due to the fact that it can function as the reservoir of bacterial infection, so the inadequate root canal treatment and obturation, i.e. its negligence may lead to the failure in the endodontic treatment $[33,34]$. 


\section{Conclusion}

Based on the obtained results, it can be concluded that the approximal (mesiodistal) projection by radiography of the decalcified teeth is more reliable than the clinical (vestibuloral). This study revealed the highest incidence of the maxillary second premolars with a single root and a single canal - Vertucci's configuration canal Type I. Certain number of

Funding source. The authors received no specific funding for this work.

Ethical approval. The Ethics Committee of the Faculty of Medicine Foca approved the study and informed consent

\section{References:}

1. Vertucci F. Root canal anatomy of the human permanent teeth. Oral Surge Oral Med Oral Pathol 1984;58(5):589-99.

2. Vertucci F. Root canal morphology and its relationship to endodontic procedures. Endodontic Topics 2005;10:3-29.

3. Tabassum S, Khan FR. Failure of endodontic treatment: the usual suspects. Eur J Dent 2016;10(1):144-7.

4. Nallapati S. Three canal mandibular first and second premolars: A treatment approach. J Endod 2005;31(6):474-6.

5. Bulut DG, Kose E, Ozcan G, Sekerci AE, Canger EM, Sisman Y. Evaluation of root morphology and root canal con-figuration of premolars in the Turkish individuals using cone beam computed tomography. Eur J Dent 2015;9(4):551-7.

6. Ahmed HMA, Cheung GS. Accessory roots and root canals in maxillary premolar teeth: a review of a critical endodontic challenge. ENDO - Endodontic Practice Today 2012;6:7 -18 .

7. Kartal N, Ozçelik B, Cimilli H. Root canal morphology of maxillary premolars. J Endod 1998;24(6):417-9. cases revealed two canals with different configurations of the canal system. These findings emphasize the importance of knowing the variations in root canal morphology, because excluding the possibility of morphological variations can lead to failure of endodontic treatment. Further research is recommended on a larger sample, with the application of modern computerized techniques for detecting different configurations of the root canal.

was obtained from all individual respondents. The research was conducted according to the Declaration of Helsinki.

Conflicts of interest. The authors declare no conflict of interest.
8. Martins NJ, Gu Y, Marques D, Francisco H, Caramês J. Differences on the Root and Root Canal Morphologies between Asian and White Ethnic Groups Analyzed by Cone-beam Computed Tomography. J Endod 2018;44(7):1096104.

9. Yang L, Chen X, Tian C, Han T, Wang Y. Use of Cone-beam Computed Tomography to Evaluate Root Canal Morphology and Locate Root Canal Orifices of Maxillary Second Premolars in a Chinese Subpopulation. J Endod 2014;40(5):630-4.

10. Abella F, Teixidó LM, Patel S, Sosa F, Duran-Sindreu F, Roig M. Cone-beam Computed Tomography Analysisof the Root Canal Morphology of Maxillary First and Second Premolars in a Spanish Population. J Endod 2015;41(8):1241-7.

11. Weine S, Healey HJ, Gerstein H, Evanson L. Canal configuration in the mesiobuccal root of the maxillary first molar and its endodontic significance. Oral Surg Oral Med Oral Pathol 1969;28(3):419-25.

12. Gulabivala K, Aung TH, Alavi A, Ng YL. Root and canal morphology of Burmese mandibular molars. Int Endod J 2001;34(5):359-70. 
13. Vertucci F, Seelig A, Gillis R. Root canal morphology of the human maxillary second premolar. Oral Surg Oral Med Oral Pathol 1974;38(3):456-64.

14. Sardar KP, Khokhar NK, Siddiqui I. Frequency of two canals in maxillary second premolar tooth. J Coll of Physicians Surg Pak 2007;17(1):12-4.

15. Atieh MA. Root and canal morphology of maxillary first premolars in a Saudi population. J Contemp Dent Pract 2008;9(1):46-53.

16. Pattanshetti N, Gaidhane M, Al Kandari AM. Root and canal morphology of the mesiobuccal and distal roots of permanent first molars in a Kuwait population - a clinical study. Int Endod J 2008;41(9):755-62.

17. de Oliveira SH, de Moraes LC, Faig-Leite H, Camargo SE, Camargo $\mathrm{CH}$. In vitro incidence of root canal bifurcation in mandibular incisors by radiovisiography. J Appl Oral Sci 2009;17(3):234-9.

18. Awawdeh L, Abdullah H, Al-Qudah A. Root form and canal morphology of Jordanian maxillary first premolars. J Endod 2008;34(8):95661.

19. Grover C, Shetty N. Methods to study root canal morphology: A review. ENDO - Endodontic Practice Today 2012;6(3):171-82.

20. Plotino G, Grande NM, Pecci R, Bedini R, Pameijer $\mathrm{CH}$, Somma F. Three-dimensional imaging using microcomputed tomography for studying tooth macromorphology. J Am Dent Assoc 2006;137(11):1555-61.

21. Javidi M, Zarei M. Vatanpour M. Endodontic treatmen of a radiculous maxillary premolar: case report. J Oral Sci 2008;50(1):99-102.

22. Arisu HD, Alacam T. Diagnosis and treatment of thee-rooted maxillary premolars. Eur J Dent 2009;3(1):62-6.

23. Okumura T. Anatomy of the root canals. J Am Dent Assoc 1927;14(4):632-36.

24. Pécora JD, Saquy PC, Sousa Neto MD, Woelfel JB. Root form and canal anatomy of maxillary first premolars Braz Dent J 1992;2(2):87-94.
25. Alavi AM, Opasanon A, Ng YL, Gulabivala K. Root and canal morphology of Thai maxillary molars. Int Endod J 2002;35(5):478-85.

26. Pineda F, Kuttler Y. Mesiodistal and buccolingual roentgenographic investigation of 7,275 root canals. Oral Surg Oral Med Oral Pathol 1972;33(1):101-10.

27. Neelakantan P, Subbarao C, Ahuja R, Subbarao CV. Root and canal morphology of Indian maxillary premolars by a modified root canal staining technique. Odontology 2011;99(1):1821.

28. Weng XL, Yu SB, Zhao SL, Wang HG, Mu T, Tang RY. Root canal morphology of permanent maxillary teeth in the Han nationality in Chinese Guanzhong area: A new modified root canal staining technique. J Endod 2009;35:651-6.

29. Rozylo TK, Miazek M, Kalinowska RI, Burdan F. Morphology of root canals in adult premolar teeth. Folia Morphol (Warsz) 2008;67:280-5.

30. Caliskan MK, Pehlivan Y, Sepetcioglu F, Turkun M, Tuncer S. Root canal morphology of human permanent teeth in a Turkish population. J Endod 1995;21:200-4.

31. Yang H, Tian C, Li G, Yang L, Han X, Wang Y. A cone-beam computed tomography study of the root canal morphol-ogy of mandibular first premolars and the location of root canal orifices and apical foramina in a Chinese subpopulation. J Endod 2013;39(4):435-8.

32. Udayakumar JR, Mylswamy. Root canal morphology of maxillary second premolars in an Indian population. J Conserv Dent 2010;13(3):148-51.

33. Sert S, Bayirli GS. Evaluation of the root canal configurations of the mandibular and maxillary permanent teeth by gender in the Turkish population. J Endod 2004;30:391-98.

34. Singla MG, Pada BK. An in vitro study of root canal morphology of maxillary second premolars. ENDO (Long Engl.) 2010;4:293-9. 


\title{
Analiza anatomije i konfiguracije kanalnog sistema drugog maksilarnog premolara u populaciji Bosne i Hercegovine
}

\author{
Brankica Davidović, Ljiljana Bjelović, Igor Radović, \\ Bojana Davidović, Svjetlana Janković, Smiljka Cicmil \\ Univerzitet u Istočnom Sarajevu, Medicinski fakultet Foča, Republika Srpska, Bosna i Hercegovina
}

\section{Kratak sadržaj}

Uvod. Uspjeh endodontskog tretmana zavisi od znanja i sposobnosti kliničara da prepozna i dijagnostikuje prisustvo anatomskih i morfoloških varijacija korijenskog i kanalnog sistema. Cilj ovog istraživanja je bio da se prikaže broj korjenova i konfiguracija korijenskih kanala drugog maksilarnog premolara u populaciji Bosne i Hercegovine.

Metode. Uzorak se sastojao od 150 maksilarnih drugih premolara ekstrahovanih iz ortodontskih ili protetskih razloga. Za trepanaciju kavuma dentis korišćena su endodontska svrdla, a prohodnost svakog korijenskog kanala i njihov broj određeni su primjenom K-proširivača \# 15. Zatim, uzorci su bili dekalcifikovani, napravljeni transparentnim i bojeni da bi se omogućio 3D prikaz kanalnog sistema. Dekalcifikovani zubi su posmatrani iz dvije projekcije (kliničke i aproksimalne) i detaljno analizirani sa lupom pod uvećanjem $3 \times$ i $5 \times$ u cilju utvrđivanja broja korjenova, broja kanala, konfiguracije korijenskih kanala primjenom Vertuči klasifikacije i broja anostomoza između kanala. Za statističku obradu podataka korišćen je Hi-kvadrat test.

Rezultati. Rezultati dobijeni dekalcifikacijom zuba drugih maksilarnih premolara su pokazali da su, analizom radiograma iz kliničke projekcije, svi zubi imali jedan korijen. Dok, analizom iz aproksimalne projekcije $94,0 \%$ imalo je jedan, a 6,0\% dva korijena. Iz aproksimalne projekcije vizuelizuje se 70,7\% sa jednim kanalom, a 29,3\% sa dva kanala. Najčešći tip konfiguracije kanala korijena kod drugih maksilarnih premolara je bio tip I kako u kliničkoj (87,9\%), tako i u aproksimalnoj projekciji (40,7\%).

Zaključak. Ovi rezultati naglašavaju značaj poznavanja varijacija u morfologiji korijenskih kanala, jer isključivanje mogućnosti morfoloških varijacija može dovesti do neuspjeha endodontske terapije.

Ključne riječi: drugi maksilarni premolar, kanal zuba, dekalcifikacija 